\title{
The Influence of Social Contact in Residents' Perceptions of the Tourism Impact on Their Quality of Life: A Structural Equation Model
}

\section{Maria João Carneiro, Celeste Eusébio \& Ana Caldeira}

To cite this article: Maria João Carneiro, Celeste Eusébio \& Ana Caldeira (2017): The Influence of Social Contact in Residents' Perceptions of the Tourism Impact on Their Quality of Life: A Structural Equation Model, Journal of Quality Assurance in Hospitality \& Tourism, DOI: 10.1080/1528008X.2017.1314798

To link to this article: http://dx.doi.org/10.1080/1528008X.2017.1314798

\section{Published online: 12 Sep 2017.}

\section{Submit your article to this journal $\square$}

Џ Article views: 6

Q View related articles ¿

\section{View Crossmark data ¿}




\title{
The Influence of Social Contact in Residents' Perceptions of the Tourism Impact on Their Quality of Life: A Structural Equation Model
}

\author{
Maria João Carneiro ${ }^{a, b, c}$, Celeste Eusébio ${ }^{a, b, c}$, and Ana Caldeira ${ }^{a, c}$ \\ ${ }^{a}$ Assistant Professor, University of Aveiro, Aveiro, Portugal; ${ }^{\text {b}}$ Researcher, GOVCOPP Research Unit, \\ University of Aveiro; 'Department of Economics, Management, Industrial Engineering and Tourism, \\ University of Aveiro, Campus Universitário de Santiago, Aveiro, Portugal
}

\begin{abstract}
This article develops and tests a structural model that illustrates relationships between host-tourist interaction (intensity and satisfaction) and tourism impacts on residents' Quality of Life (QOL). The model is tested using a survey of residents of two coastal tourism destinations located in the Central Region of Portugal. The results reveal that the social interaction has a significant impact on the resident's perceptions of the impacts of tourism on their QOL. However, this impact differs according to the domain of the QOL. Moreover, satisfaction with interaction positively influences all domains of QOL and is the construct with the second greatest total effect on the impacts of tourism on residents' overall QOL. The results highlight the relevance of stimulating a satisfying social interaction between residents and visitors in order to increase the impacts of tourism on residents' QOL. Theoretical contributions and practical implications are stated based on the results.
\end{abstract}

\section{KEYWORDS}

Host-tourist interaction; quality of life; tourism impacts; residents; perceptions; structural equation models

\section{Introduction}

In recent decades, Quality-of-Life (QOL) research has increased considerably in areas such as medicine, marketing, economics, and environmental science (Uysal, Sirgy, Woo, \& Kim, 2016). Tourism, given its characteristics, has great potential to influence the QOL of all stakeholders involved in its development process. Consequently, a growing interest in research on QOL perceptions can be noted in the field of tourism, both from the perspectives of tourists and residents (e.g., Chancellor, Yu, \& Cole, 2011; Dolnicar, Lazarevski, \& Yanamandram, 2013; Eusébio \& Carneiro, 2014; Kim, Uysal, \& Sirgy, 2013; Nawijn \& Mitas, 2012; Uysal et al., 2016; Yamada, Heo, King, $\& \mathrm{Fu}, 2011)$. Despite the widespread knowledge that tourism may have great potential for enhancing residents' QOL, a limited number of studies have

CONTACT Maria João Carneiro mjcarneiro@ua.pt E Assistant Professor, University of Aveiro, Portugal; Researcher, GOVCOPP Research Unit, University of Aveiro; Department of Economics, Management, Industrial Engineering and Tourism, University of Aveiro, Campus Universitário de Santiago, Aveiro 3810-193. Portugal. 
examined the impact of tourism on residents' QOL (e.g., Andereck \& Naupane, 2011; Andereck, Valentine, Vogt, \& Knopf, 2007; Aref, 2011; Bimonte \& Faralla, 2016; Fredline, Deery, \& Jago, 2013; Khizindar, 2012; Usher \& Kerstetter, 2014).

There is a general consensus among academics, politicians, and tourism industry representatives that it is of utmost relevance to increase the knowledge of the effect of tourism on resident's QOL (Kim, 2002; Uysal et al., 2016; Yu, Cole, \& Chancellor, 2016) and of the factors that may influence this effect. However, the research in this field is limited and highly fragmented. Several arguments could be reported that point out the importance of studying these issues. Residents are one of the most important tourism resources of a destination (Andereck et al., 2007). In this line of thought, it is of utmost relevance to analyze the residents' perception of tourism impacts on their QOL (Andereck \& Nyaupane, 2011; Andereck et al., 2007; Aref, 2011) since this perception may influence the residents' attitudes towards tourism development (Jeon, Kang, \& Desmarais, 2016). As Andereck and colleagues (2007, p. 489) state, “as tourism development becomes an increasingly popular means of economic development in diverse areas, resident perceptions regarding tourism will become increasingly more important not only to academic researchers, but also to tourism industry managers and public policymakers." Other researchers (e.g., Aref, 2011; Carneiro \& Eusébio, 2015; Eusébio \& Carneiro, 2014; Jeon et al., 2016; Kim, 2002; Uysal et al., 2016) reinforce this idea showing the relevance of developing studies regarding the impact of tourism on residents' QOL for the sustainable development of a tourism destination.

In order to implement tourism development strategies that increase the positive effect of tourism on residents' QOL, it is crucial to identify the factors that may influence this impact. The pertinent literature suggests that residents' perceptions of the impact of tourism on their QOL may be influenced by factors such as the profile of the residents, the level of development of the destination, seasonality, the economic dependence of the residents on tourism activity and the encounters that occur between residents and tourists (Andereck \& Nyaupane, 2011; Bimonte \& Faralla, 2016; Kim et al., 2013; Uysal et al., 2016). The host-tourist interactions may have an important role in the experience of both actors in the process, offering residents opportunities to know people from different cultures, to increase socialization opportunities and skills, to reduce isolation and expand social networks, to increase business opportunities, and to raise residents' pride in their place of residence (Guo, Kim, \& Chen, 2014; Karabati, Dogan, Pinar, \& Celik, 2009; Kastenholz, Carneiro, Eusébio, \& Figueiredo, 2013; Lee \& Weaver, 2014; Mai, Rahtz, \& Shultz, 2013; Su, Long, Wall, \& Jin, 2016). However, there is a gap in the literature concerning the influence of social contact with tourists on the residents' perception of the tourism impacts on their QOL (Carneiro \& Eusébio, 2012; Eusébio \& Carneiro, 2012b; Kastenholz et al., 2013). In order to overcome 
this gap, a structural equation model is developed and tested in this study in two Portuguese beach tourism destinations, to analyze the relationship between hosttourist interaction (intensity and satisfaction) and residents' perception of tourism impacts on their QOL.

Following this introduction, the article begins with a literature review regarding the two constructs analyzed in this research-the impacts of tourism on residents' QOL and host-tourist interaction. At the end of the literature review section, the structural conceptual model and hypotheses are presented. After this, the methodology used in terms of data collection methods and data analysis methods to test the conceptual model proposed is described, followed by a description and discussion of the results obtained. Finally, the article concludes with the most important theoretical contributions, practical implications, limitations and suggestions for further research.

\section{Literature review}

\section{Impact of tourism on residents' QOL}

Although in recent years the QOL topic has had a central role in political and academic discourse, there is great difficulty in defining this concept. As suggested by Andereck and colleagues (2007, p. 484), QOL is a "subjective experience dependent on an individual's perceptions and feelings." In the literature, several definitions and models to measure QOL are discussed, revealing that there is no single consensus definition and that other words, such as "wellbeing," are frequently used interchangeably with QOL (Eusébio \& Carneiro, 2014; Eusébio, Carneiro, \& Caldeira, 2016; Uysal et al., 2016). Despites there is no consensual definition of QOL, there is an agreement that this concept is a multidimensional and interactive construct including several features of people's life and environments (Andereck et al., 2007), and is measured through subjective and objective indicators (Kim, 2002; Uysal et al., 2016).

Several measures and scales have been used to measure residents' perceptions of tourism impacts on their QOL (Andereck et al., 2007; Eusébio \& Carneiro, 2014; Uysal et al., 2016). The scales developed by Kim (2002) and Andereck and Nyaupane (2011) hold a prominent role in this field. Kim (2002) considers four QOL domains-material well-being; community wellbeing, emotional well-being, and health \& safety-to analyze how tourism influences residents' QOL in tourism destinations in different development stages. Aref (2011) uses the domains proposed by Kim (2002) to investigate the effect of tourism on residents' QOL in Shiraz, Iran. Khizindar (2012) also considers the domains proposed by Kim (2002) to measure the effects of tourism on residents' QOL in Saudi Arabia. Andereck and Nyaupane (2011, p. 254) use eight domains of residents' QOL_ "community well-being," "urban issues," "way of life," "community pride and awareness," "natural 
and cultural preservation," "economic strength," "recreation amenities," and "crime and substance abuse" - to measure the impact of tourism on residents' QOL in Arizona.

The studies published regarding the impact of tourism on resident's QOL reveal that tourism may enhance several domains of resident's QOL. The tourism products developed in a tourism destination (e.g., events, food \& beverage facilities, outdoor recreation facilities) may be enjoyed by residents (Andereck \& Nyaupane, 2011; Andereck et al., 2007). Furthermore, tourism can also have an important role in improving the standard of living of local communities, contributing to an increase in household income, employment opportunities, tax revenues and economy diversity (Andereck \& Nyaupane, 2011; Andereck et al., 2007; Yu et al., 2016). Moreover, differences regarding the impact of tourism on several domains of QOL are observed in the literature. For example, in Arefs (2011, p. 28) study the strongest tourism impacts are related with "emotional well-being," "community well-being," and "income and employment," whether "health well-being" and "safety well-being" are the least influenced by tourism. There are also some references regarding the potential negative impacts of tourism on residents' QOL (e.g., crowding, some kinds of pollution, traffic and parking problems, increased crime, increased cost of living, increased friction between tourists and residents, modifications in residents' way of living) (Andereck \& Nyaupane, 2011; Andereck et al., 2007; Moscardo, 2009).

The impact of tourism on residents' QOL has been studied in various types of tourism activities and tourism destinations. For example, some studies analyze the impacts of tourism on cultural heritage tourism destinations (e.g., Jeon et al., 2016), while other studies investigate the impact of events (e.g., Fredline et al., 2013; Liu, 2015) and others examine the impact of casinos (e.g., Chhabra \& Gursoy, 2009). A limited number of studies analyze the impact of tourism on residents' QOL in coastal tourism destinations (e.g., Nawijn \& Mitas, 2012), despite the great popularity of this type of tourism destinations in various countries, as is the case of Portugal. Moreover, coastal tourism destinations reveal several differences compared to other types of tourism destinations concerning the tourism development model, the type of tourist and the economic relevance of the tourism industry (e.g., Bimonte \& Faralla, 2016; Lundberg, 2015; Nawijn \& Mitas, 2012). Usually, tourism in this type of destinations is one of the most important economic activities, with a great number of residents depending economically on this activity, with high seasonality, and may give rise to overcrowding and environmental damage. Therefore, in beach tourism destinations, it is expected that host-tourist interactions and their effects will be different from other types of tourism destinations.

A wide variety of data analysis methods has been used in studies regarding the impact of tourism on residents' QOL, from simple methods, such as descriptive analysis (e.g., Andereck \& Nyaupane, 2011; Aref, 2011; Jeon et al., 2016), to more complex methods such as cluster analysis (e.g., Fredline et al., 
2013), ANOVA and MANOVA models (e.g., Andereck et al., 2007; Chhabra \& Gursoy, 2009), exploratory factor analysis (e.g., Andereck \& Nyaupane, 2011), confirmatory factor analysis (e.g., Chhabra \& Gursoy, 2009; Jeon et al., 2016), regression models (e.g., Andereck \& Nyaupane, 2011; Chhabra \& Gursoy, 2009; Khizindar, 2012; Nawijn \& Mitas, 2012), and structural equation modeling (e.g., Jeon et al., 2016; Kim, 2002; Kim et al., 2013).

Recently, structural equation modeling has gained popularity in studies that analyze the direct and indirect effects of the factors that may influence the impact of tourism on residents' QOL. However, this type of study remains limited regarding the factors that influence residents' perceptions concerning the impact of tourism on their QOL. However, there is a vast literature concerning the determinants of residents' perception of tourism impacts on the host community (Andereck, Valentine, Knopf, \& Vogt, 2005; Bimonte \& Faralla, 2016; Bimonte \& Punzo, 2016; Eusébio \& Carneiro, 2012b; Sharpley, 2014; Wang \& Chen, 2015; Zhang, Inbakaran, \& Jackson, 2006) covering a great number of intrinsic (e.g., socioeconomic profile, economic dependence on the tourism industry, community attachment, interactions with tourists) and extrinsic factors (e.g., level of tourism development, tourist season, type of tourism/tourists). The few studies regarding the factors influencing residents' perception of tourism impacts on their QOL have only examined the influence of some determinants of this impact such as: socio-demographic factors (age, gender, education, marital status, employment) (e.g., Khizindar, 2012), seasonal factors (e.g., Bimonte \& Faralla, 2016; Jeon et al., 2016), place of residence (e.g., Andereck et al., 2007; Chancellor et al., 2011), and quality of the tourism destinations (e.g., Lipovčan, Brajša-Žganec, \& Poljanec-Borić, 2014). Despite the crucial role of host-tourist interaction in the tourism experience of visitors and residents, the studies that examine the influence of host-tourist interaction on residents' perceptions of tourism impacts, both on the host community and on the QOL of each resident (e.g., Andereck \& Nyaupane, 2011; Andereck et al., 2005; Bimonte \& Punzo, 2016; Teye, Sönmez, \& Sirakaya, 2002), are very scarce. Moreover, there is no study that analyzes the influence of host-tourist interaction on the impact of tourism on residents' QOL using a structural equation model.

The lack of studies concerning the influence of host-tourist interaction on residents' perception of tourism impacts on their QOL, as well as the relevance of this factor in decreasing social isolation, expanding social networks, increasing socialization skills, spurring business opportunities, and generating positive resident attitudes toward tourism development (Bimonte \& Punzo, 2016; Guo et al., 2014; Karabati et al., 2009; Kastenholz et al., 2013; Lee \& Weaver, 2014; Mai et al., 2013; Su et al., 2016), led to the choice to study social contact in this research. Therefore, it is of utmost importance for tourism planners and decision makers to understand how the host-tourist interaction influences the residents' perceptions of tourism impacts on their QOL, in order to develop strategies to increase social contact opportunities with tourists. 


\section{Host-tourist interaction}

This research analyzes the concept of social contact with a specific emphasis on host-tourist interaction. Social contact is a complex construct (Eusébio \& Carneiro, 2012a, 2012b; Kastenholz, Carneiro, \& Eusébio, 2015; Kastenholz et al., 2013; Reisinger \& Turner, 2003) which has been studied via several approaches. Several definitions of this construct can be found in the literature. For example, Murphy (2001, p. 51) considers that social contact is "basically the study of everyday encounters with other people." In the tourism field, social contact can be understood as a personal encounter that takes place between tourism actors, such as tourists and hosts (Eusébio \& Carneiro, 2012a). In this context, understanding these encounters is of utmost relevance for the sustainable development of tourism (Eusébio \& Carneiro, 2012a, 2012b; Zhang et al., 2006). However, as Reisinger and Turner (2003) highlight, there is not enough information on how to precisely and successfully measure tourist-host interactions. Encounters between tourists and hosts can take place when tourists purchase goods and services, when tourists ask for information, or simply when tourists and hosts go to the same place (De Kadt, 1979). Despite the relevance of understanding host-tourist interactions, little research has been carried out in this field considering the host's perspective (Andereck et al., 2005; Zhang et al., 2006). Therefore, it is urgent to extend the literature in this area in order to understand the factors that influence host-tourist interactions and the characteristics and consequences of these interactions (Eusébio \& Carneiro, 2012b; Kastenholz et al., 2013; Pizam, Uriely, \& Reichel, 2000; Reisinger \& Turner, 1998; Sinkovics \& Penz, 2009).

Host-tourist interaction is frequently formal, brief, ambiguous, temporary and unequal and unbalanced in terms of its meanings for both sides (Reisinger, 2009; Yoo \& Sohn, 2003). As Jaworski, Ewen, Thurlow and Lawson (2003, p. 157) state, "local people may be encountered and interacted to varying degrees, on a scale from basic service encounters to visits to a local person's home sharing a meal and more extended conversation." Several factors influence the intensity, characteristics and effects of host-tourist interactions. The existence of opportunities for interacting stands out as one of the most important factors-if no opportunity exists, no contact occurs (Reisinger \& Turner, 2003). The interpersonal cultural similarity and the motivations to interact are two other important factors in this social contact (Reisinger, 2009; Reisinger \& Turner, 1998; Sinkovics \& Penz, 2009). Moreover, the personal characteristics of the two actors (hosts and tourists) regarding their interests, tolerance, generosity, and willingness to listen and learn stimulate the host-tourist interactions in a positive way (Reisinger, 2009). Additionally, both parties involved evaluate the benefits and costs obtained from the interaction. The host-tourist interaction increases when it is perceived as valuable (Reisinger \& Turner, 2003); when the costs exceed the benefits obtained the host-tourist interaction tends to be smaller. 
Well-functioning relationships between residents and tourists are of crucial relevance for the satisfaction of both actors involved (Eusébio \& Carneiro, 2012a, 2012b; Kastenholz et al., 2013; Pizam et al., 2000). Satisfied residents tend to have a positive attitude towards tourists, promoting return visitation (Sinkovics \& Penz, 2009; Zhang et al., 2006). Despite the relevance of understanding the consequences of host-tourist interactions, the few studies carried out in this field from the hosts' perspective have focused mainly on the impact of these interactions on host satisfaction (e.g., Andereck et al., 2005; Pizam et al., 2000; Reisinger \& Turner, 2003; Sinkovics \& Penz, 2009; Zhang et al., 2006). Moreover, only a limited number of studies examine the relationship between host-tourist interactions and residents' perceptions of the tourism impacts (e.g., Andereck \& Nyaupane, 2011).

\section{Conceptual model}

The potential influence of host-tourist interaction on the impact of tourism on hosts' QOL has been highly neglected. Nevertheless, some research brings some light to the development of hypotheses in this scope, which are going to be tested in the present research. Social contact, namely the host-tourist interaction, is considered a crucial element for an understanding of the perceptions of hosts regarding tourism (Andereck et al., 2005; Bimonte \& Punzo, 2016; Eusébio \& Carneiro, 2012a, 2012b; Pizam et al., 2000; Sharpley, 2014). The empirical study of Andereck and Nyaupane (2011) revealed that those in contact with tourists perceived more personal benefits from tourism. However, this research does not permit an understanding of the effects of these encounters in the several domains of residents' QOL. Despite the scarcity of empirical evidence in this context, the literature provides some insights in this scope.

Several studies (e.g., Inoue, Umezaki, \& Watanabe, 2012; Karabati et al., 2009; Roehl, 1999) reveal that those with jobs related to tourism or involved in tourism for a longer period and, therefore, more likely to have commercial contacts with tourists, tend to perceive a better QOL. This is in line with the social exchange theory, according to which people interact as long as they perceive the benefits of that interaction outweigh its costs (Bimonte \& Punzo, 2016; Sharpley, 2014). Due to the commercial nature of many interactions between hosts and visitors, this social contact tends to be highly associated with socioeconomic benefits (Kastenholz et al., 2013; Polonsky et al., 2013; Reisinger \& Turner, 2003; Roehl, 1999; Sharpley, 2014). However, some research suggests that encounters in the context of touristic commercial contacts may lead to the perception of a wide range of benefits (e.g., Inoue et al., 2012). The study undertaken by Inoue and colleagues (2012) shows that those with a tourism-related job not only perceive a higher overall QOL than the remaining respondents, but also recognize greater benefits on the 
several QOL domains considered in the study-general health, physical domain, psychological domain, social relationships domain and environment domain. Interactions in the scope of tourism may contribute to a mutual intercultural exchange, with hosts also sharing daily life experiences (Karabati et al., 2009) and their knowledge. Furthermore, tourism permits residents to increase their socialization opportunities, to meet new people and reduce isolation (Bimonte \& Punzo, 2016; Chiappa \& Abbate, 2016; Eusébio \& Carneiro, 2012b; Guo et al., 2014; Kastenholz et al., 2013; Mai et al., 2013; Pizam et al., 2000; Reisinger \& Turner, 2003; Su et al., 2016).

Visitors may also contribute to hosts becoming prouder and developing a greater appreciation for the places where they live (Chiappa \& Abbate, 2016; Lee \& Weaver, 2014; Reisinger \& Turner, 2003), as well as for strengthening their identity (Huebner, 2015). In the study of Guo and colleagues (2014) the fact that residents perceive more positive cultural tourism impacts-including the opportunity to have more contact with tourists and the possibility of better understanding local culture through these contacts-tends to lead to more positive perceptions regarding two life domains: (i) leisure time (e.g., finding life more interesting than before, perceiving more opportunities to enjoy the happiness of life); and (ii) community construction (e.g., being proud of themselves as local residents). The study by Chiappa and Abbate (2016) also reveals a positive relationship between contact with tourists and the residents' perception of cruise tourism impacts on several aspects of the host community related to QOL (e.g., income, socialization, safety, preservation of environment, local supply of cultural entertainment activities, quality of restaurants, hotels, and retail facilities).

Tourism is also perceived as having a crucial role in promoting understanding among people with different characteristics, namely people of different cultures (Chiappa \& Abbate, 2016; Mathieson \& Wall, 1982; Su et al., 2016). A more in-depth contact between hosts and guests may, therefore, permit hosts to better understand tourists and, eventually, to be more tolerant of the negative impacts they provoke (Bimonte \& Punzo, 2016; Chiappa \& Abbate, 2016; Kastenholz et al., 2013; Mathieson \& Wall, 1982; Pizam et al., 2000; Su et al., 2016). Reisinger and Turner (2003) also state that social contact may contribute to improving interrelationships between people.

Although recognizing that the extent to which hosts perceive the several benefits of tourism may depend on several characteristics of the tourist-host interaction, such as the context of interaction and the hosts' expectations regarding the interaction, based on the aforementioned arguments the following hypotheses were postulated (Figure 1):

H1-The intensity of social contact with visitors (ISC) has a positive effect on residents' perceptions of the impact of tourism on several domains of their QOL 


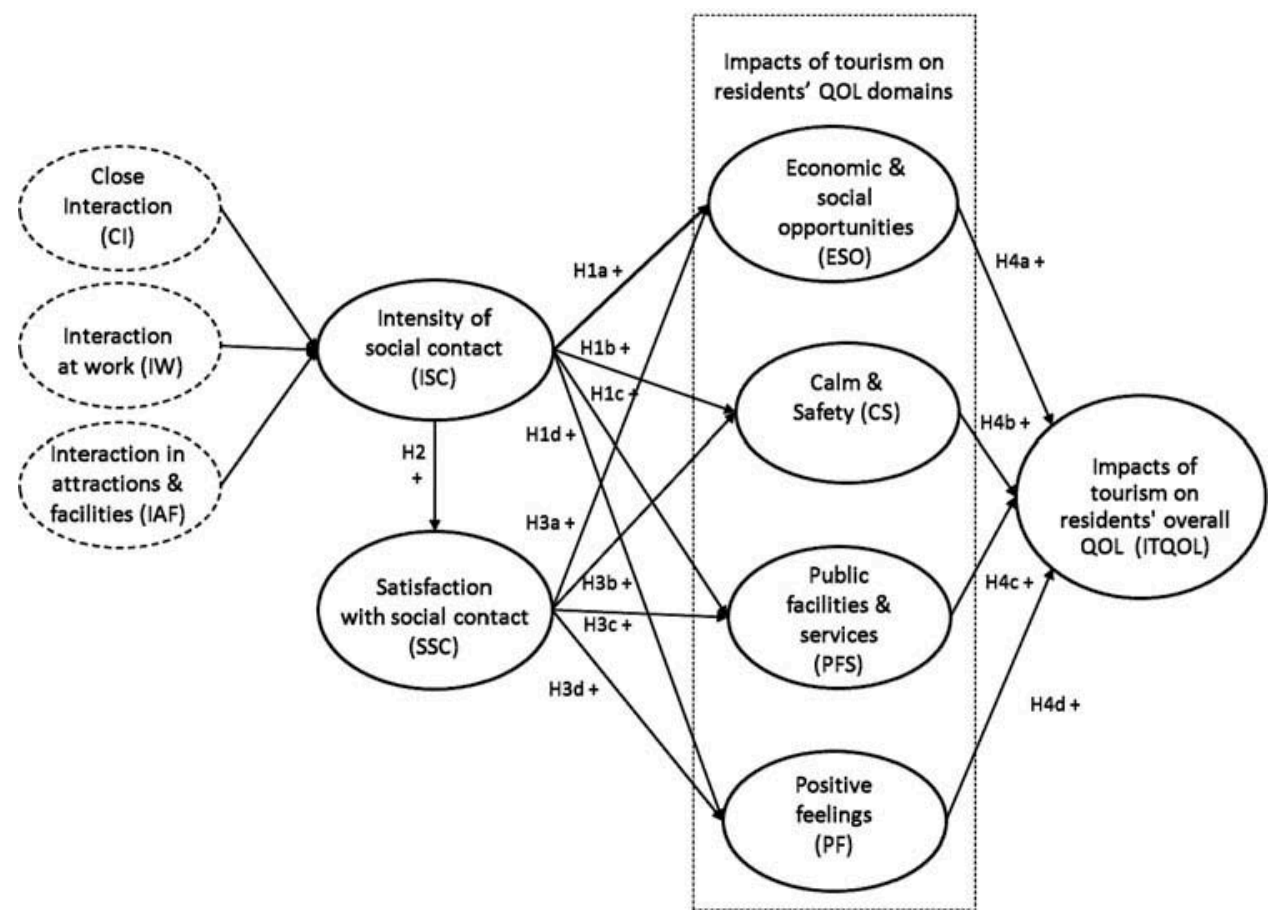

Figure 1. Conceptual model proposed.

H1a- The intensity of social contact (ISC) has a positive effect on residents' perceptions of the impact of tourism on economic \& social opportunities (ESO).

H1b - The intensity of social contact (ISC) has a positive effect on residents' perceptions of the impact of tourism on calm \& safety (CS).

H1c- The intensity of social contact (ISC) has a positive effect on residents' perceptions of the impact of tourism on public facilities \& services (PFS).

H1d- The intensity of social contact (ISC) has a positive effect on residents' perceptions of the impact of tourism on positive feelings (PF).

Despite the fact that the social contact between tourists and hosts may sometimes be, as already mentioned, unequal and unbalanced (Reisinger, 2009) and may have a prejudicial result for the host (Moscardo, Konovalov, Murphy, \& McGehee, 2013; Reisinger \& Turner, 2003; Tucker, 2003), some research (e.g., Kastenholz et al., 2013; Nawijn \& Mitas, 2012) already provides some evidences of residents perceiving interactions with tourists as very 
positive. Moreover, although contacts between residents and visitors may occur in several contexts with different objectives, it is recognized that hosttourist contacts sometimes occur because host and tourist interact in a search for personal satisfaction (Mathieson \& Wall, 1982). When discussing social exchange theory, Sharpley (2014) and Bimonte and Punzo (2016) corroborate this perspective by stating that when two parties engage in social exchanges, they tend to negotiate to obtain satisfactory results. According to this theory, exchanges will only continue until the moment the benefits obtained are higher than the costs associated with the interaction. Bimonte and Punzo (2016) also argue that hosts and tourists tend to interact in order to optimize their wellbeing. These results suggest that the contacts occurring in the context of tourism may be very rewarding. Therefore, it is hypothesized that (Figure 1):

\section{H2- The intensity of social contact with visitors (ISC) has a positive effect on the satisfaction with the social contact (SSC).}

Research on the way the satisfaction with host-tourist contact affects residents' perceptions of the impact of tourism on their QOL is even scarcer than the research supporting the previous hypotheses. The research analyzing the contact with visitors as a determinant of the impacts of tourism on residents' QOL has mainly been focused on the influence on the intensity of the interaction, neglecting the effect of the satisfaction with that interaction. However, it is recognized that host-tourist interactions may help to reduce conflict between hosts and tourists and prejudice. This would contribute to understanding and tolerance (Kastenholz et al., 2013; Mathieson \& Wall, 1982; Pizam et al., 2000; Reisinger \& Turner, 2003; Su et al., 2016; Zhang et al., 2006) and, therefore, probably to more satisfying host-tourist interactions and more positive hosts' perceptions concerning tourism impacts on their QOL.

In the study carried out by Kastenholz and colleagues (2013) the village where residents seem to be most satisfied with contacts with visitors was also the village where residents perceived that tourism offered them more opportunities to communicate with other people and to decrease their isolation. Therefore, satisfying host-tourist contacts may contribute to improving residents' QOL as far as interpersonal relationships are concerned. The research undertaken by Nawijn and Mitas (2012) corroborates this perspective in part, since the local residents' perceptions regarding the QOL domain of interpersonal relationships are positively related to their perceptions that tourism brings opportunities for local people and positively influences QOL. Moreover, in this same research, when residents consider the relation between locals and tourists as more positive they tend to have more positive perceptions regarding several domains of their QOL-family, neighborhood, 
self, services and infrastructure. Despite the scarce research in this scope, based on the literature analyzed it is postulated that (Figure 1):

H3- Satisfaction with social contact (SSC) has a positive effect on residents' perceptions of the impact of tourism on several domains of their QOL.

H3a- Satisfaction with social contact (SSC) has a positive effect on residents' perceptions of the impact of tourism on economic \& social opportunities (ESO).

H3b- Satisfaction with social contact (SSC) has a positive effect on residents' perceptions of the impact of tourism on calm \& safety (CS).

H3c- Satisfaction with social contact (SSC) has a positive effect on residents' perceptions of the impact of tourism on public facilities \& services (PFS).

H3d-Satisfaction with social contact (SSC) has a positive effect on residents' perceptions of the impact of tourism on positive feelings (PF).

Despite the importance of the impact of tourism on QOL, the way in which perceptions of tourism impact on the several domains of QOL affect residents' perceptions of the impact of tourism on the overall QOL has not been deeply addressed. However, some studies have already analyzed this issue within the scope of visitors (e.g., Eusébio \& Carneiro, 2014; Eusébio et al., 2016) and findings show that perceptions of tourism impacts on several domains of visitors' QOL (e.g., health, socialization, psychological aspects and environmental context) have a positive influence on the perceptions of tourism impacts on the visitors' overall QOL.

Mai and colleagues (2013) emphasized the fact that the domains of social, environmental, and economic QOL influence the overall perceptions of community QOL. Jeon and colleagues' (2016) research shows that the perception of economic benefits and environmental sustainability positively influences the perceptions of QOL, while the perception of social costs has a negative impact on perceptions of QOL. In the study of Kim and colleagues (2013), life satisfaction is positively influenced by perceptions of material well-being and of health and safety, suggesting that income and employment, as well as health and safety, have a very important influence in the way residents perceive their life. Nawijn and Mitas' (2012) research, carried out in Palma de Mallorca (Spain), suggests that the improvements of the overall QOL of hosts caused by tourism are primarily associated with economic issues (such as a person's overall economic situation and particularly their jobs), but also with the improvement of infrastructures and social domains of life (friends, family and interpersonal relationships). The study of Polonsky and colleagues (2013), 
undertaken in the Turkish Gallipoli Peninsula, also corroborates that the hosts' perception of global QOL is positively influenced both by the hosts' perspectives concerning impacts of tourism on economic QOL and social QOL, with the economic domain having a higher impact in this scope. Woo, Kim, and Uysal (2015) also found a positive relationship between both the material and nonmaterial well-being QOL domains and the overall QOL, in a sample of residents in four states of the United States. However, in this case the association of the non-material domain (health life, emotional life and community life) with overall QOL is slightly higher.

The findings presented are not consensual regarding the QOL domains where the impact of tourism can result in higher impacts on QOL. However, all the studies mentioned above (Jeon et al., 2016; Kim et al., 2013; Mai et al., 2013; Nawijn \& Mitas, 2012; Polonsky et al., 2013) reveal positive relationships between the perceptions of QOL domains and overall QOL. Consequently, it is posited that (Figure 1):

H4- Residents' perceptions of the impacts of tourism on several domains of their QOL has a positive effect on perceptions of the impacts of tourism on their overall QOL (ITQOL).

H4a-Residents' perceptions of the impact of tourism on economic \& social opportunities (ESO) has a positive effect on residents' overall QOL (ITQOL).

$H 4 b$ - Residents' perceptions of the impact of tourism on calm \& safety (CS) has a positive effect on residents' overall QOL (ITQOL).

H4c-Residents' perceptions of the impact of tourism on public facilities \& services (PFS) has a positive effect on residents' overall QOL (ITQOL).

H4d-Residents' perceptions of the impact of tourism on positive feelings (PF) has a positive effect on residents' overall QOL (ITQOL).

\section{Methodology}

\section{Data collection}

To test the conceptual model proposed above, a questionnaire was administered during the month of May 2012 to the residents of the two coastal communities-Barra and Costa Nova-located in the municipality of Ílhavo (which had, according to the 2011 population Census, a population of 38,549 residents) (INE, 2012), in the Central Region of Portugal. These two coastal 
communities are contiguous and very close to the city of Aveiro. Costa Nova is known for its candy-striped beachside houses and Barra for the tallest lighthouse in Portugal. Both beaches have a Blue Flag and the Flag of Accessible Beaches, being in demand both by domestic and foreign visitors. Tourism has been growing and nowadays has a prominent role in these two communities, since a great number of residents depend directly or indirectly on this economic activity. Therefore, in order to ensure a sustainable development of these two communities, it was considered of utmost importance to analyze how social contact with tourists (intensity and satisfaction) influenced the residents' perceptions of tourism impacts on their QOL.

The questionnaire used was designed based on an extensive literature regarding the impacts of tourism on residents' QOL and host-tourist interactions. The questions are organized into four groups: (i) residents' perceptions of the impacts of tourism on their QOL (overall QOL and several domains of QOL); (ii) frequency of host-tourist interactions in several contexts; (iii) level of satisfaction with host-tourist interactions; and (iv) socioeconomic profile.

Two approaches were used to measure residents' perceptions of the impacts of tourism on their QOL. To measure the impact of tourism on several domains of residents' QOL, 20 items selected from an extensive literature review on tourism and residents' QOL studies (e.g., Andereck \& Nyaupane, 2011; Andereck et al., 2007; Khizindar, 2012) and on perceived tourism impact studies (e.g., Andereck et al., 2005; Carneiro \& Eusébio, 2011) were used. To measure residents' perception of the impact of tourism on their overall QOL, only one item was used. In both cases the respondents have to indicate their level of agreement with the items using a 7-point Likert scale where 1 = completely disagree and $7=$ completely agree.

Social contact was measured through the frequency of host-tourist interactions in several contexts. To measure this construct, 13 items, selected based on a literature review about host-tourist interactions (e.g., De Kadt, 1979; Eusébio \& Carneiro, 2012a, 2012b; Reisinger \& Turner, 1998) were used. The respondents were invited to report, on a 7-point Likert-type scale where $1=$ never and 7 = very frequently, the level of frequency of their interaction with visitors. Moreover, the satisfaction level of residents with their interactions with visitors was also measured using a 7-point Likert-type scale, where $1=$ very unsatisfied and $7=$ very satisfied.

Finally, the questionnaire ends with some questions related to the sociodemographic profile of residents (e.g., place of residence, duration of residence in the coastal community, job, gender, age, education level and economic activity status).

The population of the study were the residents of the two communities who were over 14 years old. It was decided to administer the same amount of questionnaires (175) in each community. The survey was undertaken with 
personal administration of the questionnaire using a quota sampling approach, based on gender and age. The adoption of the quota sampling approach aimed to ensure that the different groups (quotas) of the population were represented in the sample in the same proportion that they were found in the population. In order to define the quotas, first, the population of each community was divided into three age cohorts (15-24 years, 25-64 years, and > 64 years) and, subsequently, in each age cohort, the number of male and female residents was determined. A total of six quotas were identified. After defining the amount of people of each group (quota) who should be interviewed, researchers selected the respondents through convenience criteria. The researchers first asked residents if they were available to participate in the survey and then requested them to indicate their age. When the number of questionnaires required to achieve each quota had been administered, no more people in that quota were surveyed.

In order to ensure that the questions were appropriately designed and, therefore, could be correctly understood by the respondents and permitted to collect the required data, a pilot test was conducted with 15 residents in the communities under analysis. Only minor changes were introduced regarding the language and order of the questions. A total of 308 valid questionnaires (138 administered in Barra and 170 in Costa Nova) were obtained and considered for further analyses.

\section{Data analysis}

Two Principal Component Analyses (PCA), one on social contact and another on tourism impacts on residents' QOL, were carried out in order to identify dimensions of these two constructs. A Partial Least Squares Structural Equation Modeling (PLS-SEM), using the SmartPLS 3.0 programme (Ringle, Wende, \& Becker, 2014), was adopted to test the research model proposed (Figure 1). Regarded as a variance-based approach to SEM (Hair, Hult, Ringle, \& Sarstedt, 2014), in contrast to covariance-based SEM, PLS is more appropriate for predictive studies and theory building (Gefen, Straub, \& Boudreau, 2000). Thus, as this study represents an initial attempt to explore the contributions of the host-tourist interaction to residents' QOL, PLS was considered to be the most appropriate. Given the flexibility of this multivariate analysis method (Ayeh, Au, \& Law, 2013), PLS algorithm has been increasingly applied to tourism research (Lee, Hallak, \& Sardeshmukh, 2016; Rasoolimanesh, Jaafar, Kock, \& Ramayah, 2015; Wu, Lan, \& Lee, 2012). The estimation procedure for PLS-SEM accommodates non-normally distributed data, which often occurs in behavioral studies (Chin, 1998). Therefore, normality in the distribution was not checked for. Moreover, constructs with fewer items or just one can be used as well as formative constructs, are relevant characteristics for the analysis of the proposed model. 


\section{Discussion}

The sample is composed by $55 \%$ of respondents living in Costa Nova and $45 \%$ in Barra. The sample is quite balanced in terms of gender ( $48 \%$ female), there is a great diversity in terms of level of education, with a dominance of residents between 25 and 60 years old (66\%) and with low incomes $(60 \%$ have a household monthly net income lower than $1000 €)$. Regarding economic activity status, the majority are employed (48.7\%), retired (16.3\%), unemployed (13.1\%) and students (11.1\%). About $27 \%$ of respondents have a job related to tourism and about $64 \%$ have lived in this community for more than 5 years.

The social contact construct is represented by three dimensions: (i) close interaction (CI); (ii) interaction at work (IW); and (iii) interaction in attractions \& facilities (IAF) (Table 1, Appendix 1). Social contact is very low in all the contexts analyzed (lower than 4 on a seven-point Likert-type scale), and was especially low regarding close contacts (e.g., exchanging gifts with visitors and practicing sports with visitors), corroborating other studies that also reveal a brief, superficial, temporary and frequently formal social tourist-host interaction (Eusébio \& Carneiro, 2012a, 2012b; Kastenholz et al., 2013; Reisinger \& Turner, 1998; Yoo \& Sohn, 2003). However, residents reveal a high satisfaction with that interaction (5.34 on a 7-point Likert-type scale), which highlights the relevance of promoting social contacts between hosts and tourists.

Residents' perceptions of the impacts of tourism on their QOL were assessed through the impacts on the overall QOL and on the following domains of this construct: (i) economic \& social opportunities (ESO); (ii) calm \& safety (CS); (iii) public facilities \& services (PFS); and (iv) positive feelings (PF) (Table 2, Appendix 2). Residents perceive high tourism impacts on all of their QOL domains (higher than 4.8 in a seven-point Likert scale) and on their overall QOL (5.26 in the same scale). However, the tourism impacts are particularly high on the psychological domain (positive feelings) and on the improvement of the environmental context (economic \& social opportunities and public facilities \& services). These results are in line with some previous research, such as that carried out by Andereck and Nyaupane (2011) and by Aref (2011). According to Aref's (2011) research, the residents perceive that tourism has its highest impacts on some domains of their QOL, such as "emotional wellbeing," "community well-being," and "income and employment."

Following the estimation procedure for PLS, the analysis encompassed two stages. In order to validate the constructs' measures before assessing the hypothesized relations between the latent constructs, first the evaluation of the measurement (outer) model was carried out and, in a second phase, the structural (inner) model was assessed. 
Table 1. Measurement statistics of social contact.

\begin{tabular}{|c|c|c|c|c|c|c|}
\hline Host-Tourist Interaction & Mean & $\begin{array}{l}\text { Standard } \\
\text { Deviation }\end{array}$ & $\begin{array}{l}\text { Indicator } \\
\text { Loadings }\end{array}$ & $t$-value ${ }^{a}$ & $\begin{array}{l}\text { Composite } \\
\text { reliability } \\
\text { (CR) }\end{array}$ & $\begin{array}{c}\text { Average } \\
\text { Variance } \\
\text { Extracted } \\
\text { (AVE) }\end{array}$ \\
\hline Close interaction $(\mathrm{Cl})$ & 2.11 & 1.34 & & & .91 & .68 \\
\hline Inviting visitors to one's home & 2.03 & 1.70 & .83 & 32.73 & & \\
\hline Practicing sports with visitors & 1.98 & 1.49 & .77 & 20.38 & & \\
\hline $\begin{array}{l}\text { Participating in parties with } \\
\text { visitors }\end{array}$ & 2.68 & 1.84 & .82 & 35.77 & & \\
\hline Sharing meals with visitors & 2.11 & 1.64 & .86 & 41.53 & & \\
\hline Exchanging gifts with visitors & 1.75 & 1.47 & .83 & 25.84 & & \\
\hline Interaction at work (IW) & 3.90 & 1.74 & & & .85 & .66 \\
\hline $\begin{array}{l}\text { Connecting with visitors in the } \\
\text { workplace }\end{array}$ & 3.52 & 2.44 & .82 & 28.60 & & \\
\hline $\begin{array}{l}\text { Providing visitors with } \\
\text { information about the } \\
\text { municipality }\end{array}$ & 4.74 & 1.74 & .75 & 21.56 & & \\
\hline $\begin{array}{l}\text { Interacting with visitors when } \\
\text { providing them with goods and } \\
\text { services }\end{array}$ & 3.45 & 2.23 & .86 & 43.63 & & \\
\hline $\begin{array}{l}\text { Interaction in attractions \& } \\
\text { facilities (IAF) }\end{array}$ & 3.91 & 1.41 & & & .86 & .56 \\
\hline $\begin{array}{l}\text { Contacting with visitors on the } \\
\text { beach }\end{array}$ & 4.16 & 1.96 & .80 & 33.56 & & \\
\hline $\begin{array}{l}\text { Contacting with visitors in } \\
\text { events }\end{array}$ & 3.30 & 1.80 & .67 & 14.73 & & \\
\hline $\begin{array}{l}\text { Contacting with visitors in food } \\
\text { and beverage establishments }\end{array}$ & 4.71 & 1.76 & .73 & 20.20 & & \\
\hline $\begin{array}{l}\text { Contacting with visitors in } \\
\text { other commercial } \\
\text { establishments }\end{array}$ & 4.09 & 1.80 & .79 & 29.01 & & \\
\hline $\begin{array}{l}\text { Contacting with visitors in } \\
\text { discos, clubs and bars }\end{array}$ & 3.31 & 2.07 & .77 & 30.46 & & \\
\hline $\begin{array}{l}\text { Residents' satisfaction with social } \\
\text { contact (SSC) }\end{array}$ & 5.34 & 1.38 & 1 & - & 1 & - \\
\hline
\end{tabular}

${ }^{\mathrm{a}} \mathrm{t}$-values were obtained with the bootstrapping procedure (5000 samples) and are significant at the .001 level (two-tailed test)

\section{Measurement model}

The research model includes both reflective and formative constructs. All first-order constructs are reflective, while the second-order construct-intensity of social contact (ISC) with visitors-is formative. The assessment of the measurement model will focus on the evaluation of reflective constructs first and afterwards on the formative construct.

\section{Reflective constructs}

Reflective constructs were assessed by analyzing the reliability of the multiple-item scales, as well as convergent validity and discriminant validity (Hair et al., 2014; Henseler, Ringle, \& Sinkovics, 2009). 
Table 2. Measurement statistics of tourism impacts on residents' QOL.

\begin{tabular}{|c|c|c|c|c|c|c|}
\hline $\begin{array}{l}\text { Tourism impacts on residents' } \\
\text { QOL }\end{array}$ & Mean & $\begin{array}{l}\text { Standard } \\
\text { Deviation }\end{array}$ & $\begin{array}{l}\text { Indicator } \\
\text { Loadings }\end{array}$ & $t$-value ${ }^{\mathrm{a}}$ & $\begin{array}{l}\text { Composite } \\
\text { reliability } \\
\text { (CR) }\end{array}$ & $\begin{array}{c}\text { Average } \\
\text { Variance } \\
\text { Extracted } \\
\text { (AVE) }\end{array}$ \\
\hline $\begin{array}{l}\text { Economic \& social opportunities } \\
\text { (ESO) }\end{array}$ & 5.39 & 1.19 & & & .92 & .63 \\
\hline $\begin{array}{l}\text { Having the opportunity to } \\
\text { carry on recreational activities }\end{array}$ & 5.30 & 1.46 & .82 & 28.94 & & \\
\hline Having more job opportunities & 5.27 & 1.71 & .79 & 25.25 & & \\
\hline $\begin{array}{l}\text { Having opportunities to get } \\
\text { more financial resources }\end{array}$ & 5.13 & 1.62 & .78 & 24.73 & & \\
\hline $\begin{array}{l}\text { Having the opportunity to } \\
\text { participate in cultural activities }\end{array}$ & 5.21 & 1.50 & .84 & 32.63 & & \\
\hline $\begin{array}{l}\text { Having opportunities for } \\
\text { socialising }\end{array}$ & 5.53 & 1.39 & .84 & 41.58 & & \\
\hline $\begin{array}{l}\text { Having opportunities for } \\
\text { contacting with people of } \\
\text { different cultures }\end{array}$ & 5.80 & 1.28 & .71 & 17.44 & & \\
\hline $\begin{array}{l}\text { Having diversity of economic } \\
\text { activities }\end{array}$ & 5.49 & 1.43 & .81 & 30.08 & & \\
\hline Calm \& safety (CS) & 4.86 & 1.51 & & & .93 & .72 \\
\hline Having a healthy life & 5.26 & 1.67 & .85 & 38.47 & & \\
\hline $\begin{array}{l}\text { Living in an unpolluted } \\
\text { environment }\end{array}$ & 4.98 & 1.78 & .88 & 50.80 & & \\
\hline Feeling safe & 5.11 & 1.71 & .85 & 36.28 & & \\
\hline $\begin{array}{l}\text { Living in uncongested } \\
\text { environments }\end{array}$ & 4.24 & 1.89 & .78 & 21.36 & & \\
\hline Living in a quiet environment & 4.64 & 1.84 & .88 & 51.34 & & \\
\hline Public facilities \& services (PFS) & 5.46 & 1.24 & & & .91 & .62 \\
\hline $\begin{array}{l}\text { Having facilities to promote } \\
\text { mobility/acessibility }\end{array}$ & 5.40 & 1.60 & .80 & 25.78 & & \\
\hline $\begin{array}{l}\text { Having access to health } \\
\text { services }\end{array}$ & 5.20 & 1.83 & .79 & 23.84 & & \\
\hline $\begin{array}{l}\text { Having access to good } \\
\text { transport }\end{array}$ & 5.52 & 1.59 & .84 & 30.91 & & \\
\hline $\begin{array}{l}\text { Preserving the natural } \\
\text { environment }\end{array}$ & 5.35 & 1.49 & .80 & 30.19 & & \\
\hline Preserving cultural heritage & 5.31 & 1.54 & .82 & 35.40 & & \\
\hline $\begin{array}{l}\text { Having restaurants and other } \\
\text { commercial establishments }\end{array}$ & 5.89 & 1.27 & .68 & 12.32 & & \\
\hline Positive feelings (PF) & 5.46 & 2.13 & & & .77 & 64 \\
\hline $\begin{array}{l}\text { Feeling proud to live in this } \\
\text { place }\end{array}$ & 5.72 & 3.36 & .62 & 3.53 & & \\
\hline Having positive feelings & 5.19 & 1.71 & .95 & 55.04 & & \\
\hline $\begin{array}{l}\text { Impacts of tourism on residents' } \\
\text { overall QOL (ITQOL) }\end{array}$ & 5.26 & 1.65 & 1 & - & & \\
\hline
\end{tabular}

${ }^{\mathrm{a}} t$-values were obtained with the bootstrapping procedure (5000 samples) and are significant at the .001 level (two-tailed test)

As it is considered a more accurate measurement than Cronbach's alpha (Fornell \& Larcker, 1981), composite reliability was used to check the reliability of the constructs, ranging from .77 to .93 (Tables 1 and 2), clearly exceeding the recommended threshold value of .70 (Bagozzi \& Yi, 1988). Moreover, all factor loadings are equal to or greater than .62 , exceeding the threshold value of .60 
suggested in the literature (Henseler et al., 2009). Average Variance Extracted (AVE) was employed to test convergent validity. As presented in Tables 1 and 2, all first-order constructs reveal an AVE higher than .50, going from .56 to .72, which attests to a suitable convergent validity of the scales used.

Discriminant validity was evaluated following Fornell and Larcker (1981) guidelines and also by the new and more demanding criterion proposed by Henseler, Ringle, and Sarstedt (2014): the heterotrait-monotrait (HTMT) ratio of correlations. The constructs in the study satisfy the discriminant validity assessment on the basis of HTMT, whether taking into account both the threshold values of .85 or .90 stated by the authors (Table 3 ), confirming that the constructs are distinct and more strongly related to their own measures than to any other construct. Therefore, these results provide support for the overall quality of the reflective constructs' measures.

\section{Formative constructs}

In the presence of a second-order formative factor model, the repeated indicators method was applied for estimation (Chin, Marcolin, \& Newsted, 2003; Hair et al., 2014). The quality assessment of the second-order formative construct-intensity of social contact (ISC) with visitors-included in the conceptual model proposed (Figure 1) comprised three stages. First, the evaluation of first-order constructs that compose the second-order construct was already stated in the previous section, since all first-order construct are reflective. Second, the multicollinearity among the first-order constructs was examined. Lastly, the weights of the first-order constructs on the secondorder constructs and their significance level were examined.

The multicollinearity was analyzed through the Variation Inflation Factor (VIF). The VIF values discard collinearity problems, varying between 1.00 and 2.40, clearly below 5 as suggested by Hair, Ringle, and Sarstedt (2013). As shown in Table 4, all first-order constructs' weights influence the secondorder construct positively, being significant and higher than .10, as suggested in the literature. Close interaction (CI) and interaction in attractions \& facilities (IAF) stand out as the first-order constructs with most impact in the second-order construct-ISC-whereas interaction at work (IW)

Table 3. Discriminant validity of the constructs-Heterotrait-Monotrait Ratio (HTMT).

\begin{tabular}{llllllllll}
\hline Constructs & Cl & IW & IAF & SSC & ESO & CS & PFS & PF & ITQOL \\
\hline CI & & & & & & & & & \\
IW & .45 & & & & & & & & \\
IAF & .57 & .44 & & & & & & & \\
SSC & .26 & .57 & .31 & & & & & & \\
ESO & .15 & .37 & .20 & .38 & & & & & \\
CS & .33 & .51 & .30 & .38 & .48 & & & & \\
PFS & .16 & .30 & .19 & .34 & .82 & .53 & & & \\
PF & .25 & .52 & .26 & .51 & .72 & .64 & .71 & & \\
ITQOL & .21 & .38 & .11 & .33 & .61 & .50 & .65 & .72 & \\
\hline
\end{tabular}


Table 4. Weights of the first-order constructs on the second-order construct*.

\begin{tabular}{llccc}
\hline 2nd Order Construct & \multicolumn{1}{c}{ 1st Order Constructs } & Weight & $t$-value & $p$ value \\
\hline \multirow{3}{*}{ Intensity of social contact (ISC) } & Close Interaction (Cl) & .53 & 14.95 & .000 \\
& Interaction at work (IW) & .33 & 10.97 & .000 \\
& Interaction in attractions \& facilities (IAF) & .42 & 13.33 & .000 \\
\hline
\end{tabular}

*Based on 5000 bootstraps.

registered the lowest influence. These findings clearly evidence the importance of promoting informal interaction with tourists, as highlighted by several researchers (DeKadt, 1979; Eusébio \& Carneiro, 2012a, 2012b; Kastenholz et al., 2015; Reisinger \& Turner, 2003).

\section{Structural model}

After ensuring the measurement model reliability and validity, the structural model-which tests the hypotheses proposed in the conceptual model (Figure 1) -was considered, examining both the model's predictive power and the relationships between the constructs (Figure 2). The path coefficients and significance levels reveal the relationships between the constructs in the conceptual model (Table 5), with $t$-values being obtained with the bootstrapping procedure (5000 samples). Additionally, the indirect and total effects of the exogenous constructs on the endogenous ones were also examined, as supplementary information regarding the cause-effect relationships (Table 6).

The explained variance $\left(R^{2}\right)$ and Stone-Geisser's criterion $\left(Q^{2}\right)$ were observed to evaluate the predictive power of the research model. Since the $R^{2}$ values vary between .12 and .50 and the $Q^{2}$ values range from .10 to .49 (Figure 2), the model reveals an acceptable prediction power, establishing the predictive importance of endogenous constructs. The construct with highest variance explained by the model is the impacts of tourism on residents' overall QOL (ITQOL), followed by calm \& safety (CS) QOL domain $\left(R^{2}=.21\right)$. On the other hand, the model only explained $11.6 \%$ of public facilities \& services (PFS) QOL domain.

All the hypotheses under analysis are supported (Figure 2 and Table 5). The hypothesis predicting that intensity of social contact (ISC) with visitors has a positive impact on residents' satisfaction with this social contact (SSC) is clearly confirmed, registering the strongest impact of the model $(\beta=.41$, $p<.001)$. This reveals the importance of increasing interaction opportunities with visitors since, as already argued by some researchers (e.g., Eusébio \& Carneiro, 2012a, 2012b; Kastenholz et al., 2013; Pizam et al., 2000; Reisinger \& Turner, 2003), a greater host-tourist interaction may result in more satisfying contacts. 
Table 5. Hypotheses testing results.

\begin{tabular}{|c|c|c|c|c|c|}
\hline Hypotheses & Coefficients & Standard Error & t-value & $p$ value & Result \\
\hline H1a: ISC $\rightarrow$ ESO & .11 & .053 & 2.07 & .039 & Supported \\
\hline $\mathrm{H} 1 \mathrm{~b}: \mathrm{ISC} \rightarrow \mathrm{CS}$ & .30 & .053 & 5.74 & .000 & Supported \\
\hline H1c: ISC $\rightarrow$ PFS & .10 & .052 & 1.88 & .060 & Supported $^{\mathrm{a}}$ \\
\hline $\mathrm{H} 1 \mathrm{~d}: \mathrm{ISC} \longrightarrow \mathrm{PF}$ & .16 & .047 & 3.35 & .001 & Supported \\
\hline $\mathrm{H} 2: \mathrm{ISC} \longrightarrow \mathrm{SSC}$ & .41 & .048 & 8.56 & .000 & Supported \\
\hline H3a: SSC $\longrightarrow$ ESO & .32 & .067 & 4.83 & .000 & Supported \\
\hline $\mathrm{H} 3 \mathrm{~b}: \mathrm{SSC} \rightarrow \mathrm{CS}$ & .24 & .067 & 3.66 & .000 & Supported \\
\hline $\mathrm{H} 3 \mathrm{c}: \mathrm{SSC} \rightarrow \mathrm{PFS}$ & .29 & .065 & 4.48 & .000 & Supported \\
\hline $\mathrm{H} 3 \mathrm{~d}: \mathrm{SSC} \longrightarrow \mathrm{PF}$ & .33 & .055 & 6.02 & .000 & Supported \\
\hline H4a: ESO—> ITQOL & .16 & .090 & 1.81 & .071 & Supported $^{\mathrm{a}}$ \\
\hline H4b: CS— ITQOL & .13 & .057 & 2.36 & .018 & Supported \\
\hline H4c: PFS—> ITQOL & .27 & .079 & 3.42 & .001 & Supported \\
\hline H4d: PF-> ITQOL & .29 & .082 & 3.54 & .000 & Supported \\
\hline
\end{tabular}

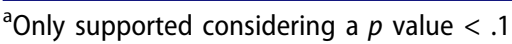

Table 6. Direct, indirect and total effects*.

\begin{tabular}{lccccc}
\hline & & & & \multicolumn{2}{c}{ Total } \\
\cline { 3 - 6 } Path & Direct & Indirect & coefficient & $t$-value & $p$ value \\
\hline ISC-> ESO & .11 & .13 & .24 & 4.580 & .000 \\
ISC-> CS & .30 & .10 & .40 & 9.300 & .000 \\
ISC-> PFS & .10 & .12 & .22 & 4.000 & .000 \\
ISC-P PF & .16 & .13 & .29 & 6.400 & .000 \\
ISC-> ITQOL & - & .24 & .24 & 6.120 & .000 \\
ISC-> SSC & .41 & - & .41 & 8.560 & .000 \\
SSC-> ESO & .32 & - & .32 & 4.830 & .000 \\
SSC-> CS & .24 & - & .24 & 3.660 & .000 \\
SSC-> PFS & .29 & - & .29 & 4.480 & .000 \\
SSC-> PF & .33 & - & .33 & 6.020 & .000 \\
SSC-> ITQOL & - & .26 & .26 & 5.760 & .000 \\
ESO-> ITQOL & .16 & - & .16 & 1.810 & .071 \\
CS-> ITQOL & .13 & - & .13 & 2.360 & .018 \\
PFS-> ITQOL & .27 & - & .27 & 3.420 & .001 \\
PF-> ITQOL & .29 & - & .29 & 3.540 & .000 \\
\hline
\end{tabular}

*Based on 5000 bootstrap samples.

The findings also confirm a positive and significant influence of intensity of social contact (ISC) with visitors on QOL domains (Hypotheses 1a to 1d), especially on calm \& safety (CS) $(\beta=.30, p<.001)$ and on positive feelings (PF) $(\beta=.16, p<.001)$. Moreover, the significant indirect effect of intensity of social contact (ISC) on the impacts of tourism on residents' overall QOL (ITQOL) which was observed (Table 6) highlights the importance of encounters between hosts and tourists and reinforces the relevance of promoting intense host-tourist contacts. Residents' satisfaction with social contact (SSC) was found to significantly influence all the QOL domains, with its highest impacts being on positive feelings $(\beta=.33, p<.001)$ and economic $\&$ social relationship opportunities $(\beta=.32$, $p<.001)$. These results reveal that the encounters between visitors and residents may have a crucial role in decreasing social isolation, expanding social networks, increasing socialization skills, raising business opportunities and generating 


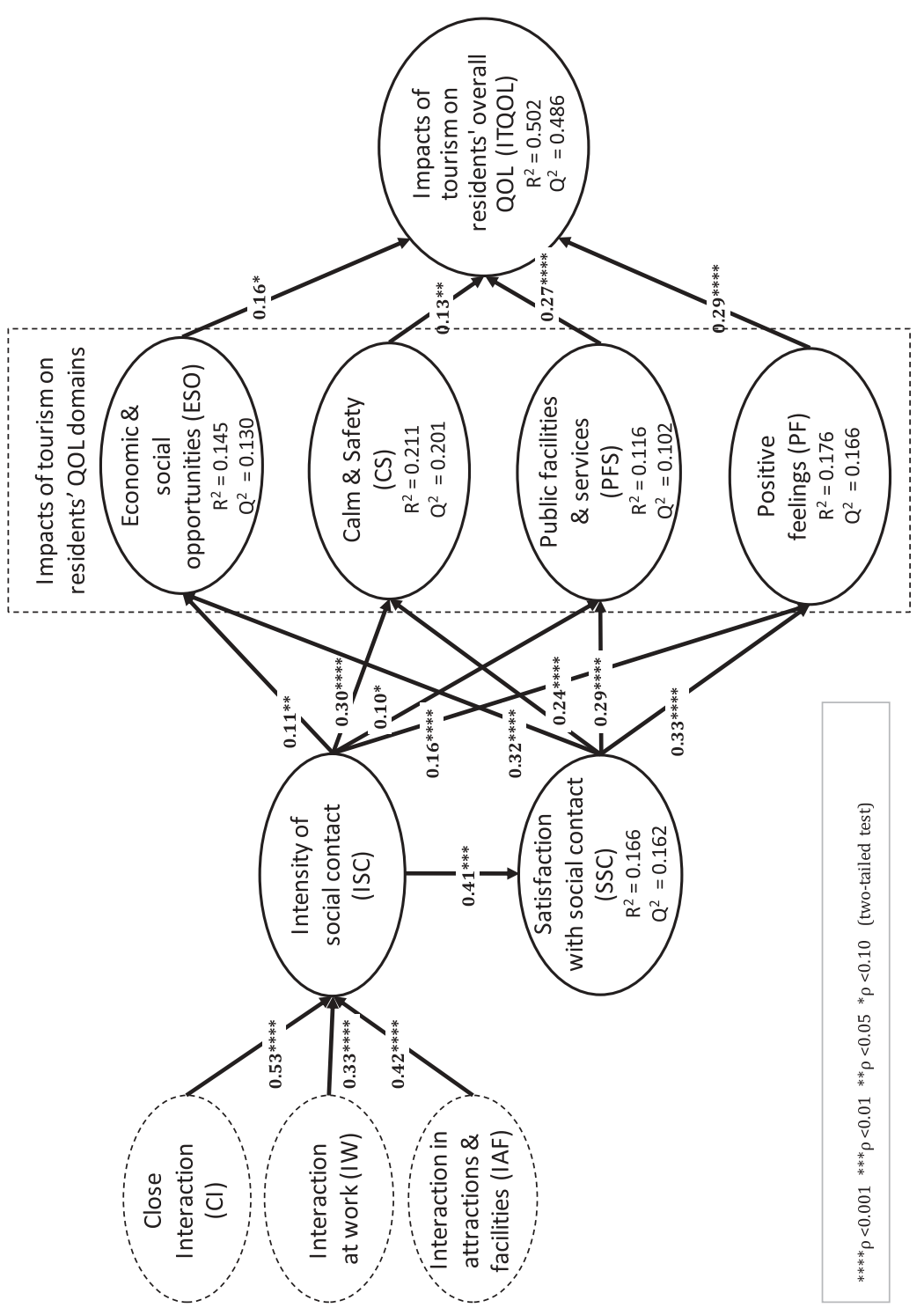

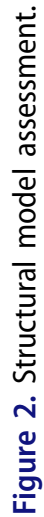


positive resident attitudes toward tourism development, as highlighted by some previous studies (Bimonte \& Punzo, 2016; Guo et al., 2014; Karabati et al., 2009; Kastenholz et al., 2013; Lee \& Weaver, 2014; Mai et al., 2013; Su et al., 2016).

These findings emphasize that it is not enough to stimulate host-tourist contacts, but it is of utmost relevance to ensure pleasant encounters. In fact, besides a significant indirect effect on overall QOL, satisfaction with social contact (SSC) registers an indirect effect on all residents' QOL domains as well (Table 6). In order to examine if the latter construct has a mediator effect between the intensity of social contact (ISC) and the perceptions of tourism impacts on residents' QOL domains (ESO, SC, PFS, PF), as suggested by Hair and colleagues (2014), the variance accounted for (VAF) was calculated. According to these authors, no mediation exists if the VAF value is lower than $20 \%$, whether a VAF between $20 \%$ and $80 \%$ denotes partial mediation and a VAF higher than $80 \%$ corresponds to a full mediation. The VAFs obtained $\quad(\mathrm{ISC} \rightarrow \mathrm{SSC} \rightarrow \mathrm{ESO}=54.5 \%, \quad \mathrm{ISC} \rightarrow \mathrm{SSC} \rightarrow \mathrm{CS}=24.8 \%$, $\mathrm{ISC} \rightarrow \mathrm{SSC} \rightarrow \mathrm{PFS}=54.8 \%, \mathrm{ISC} \rightarrow \mathrm{SSC} \rightarrow \mathrm{PF}=46.1 \%)$ indicate that the satisfaction with social contact (SC) partially mediates all the four relationships between intensity of social contact (ISC) and the perceptions of tourism impacts on residents' QOL domains (ESO, SC, PFS, PF).

Finally, the Hypotheses $4 \mathrm{a}$ to $4 \mathrm{~d}$ proposed that residents' perceptions of the impacts of tourism on several domains of their QOL influence their perceptions of the impacts of tourism on their overall QOL. Results confirm this positive effect in all the four hypotheses. The positive feelings domain recorded the strongest and positive effect on overall QOL $(\beta=.29, p<.001)$, followed by public facilities \& services $(\beta=.27, p<.001)$. These findings highlight the relevance of both material and non-material domains of QOL as remarked by Nawijn and Mitas (2012) and Woo and colleagues (2015). Considering that positive feelings is the QOL domain with the highest impact on residents' overall QOL, and the great potential of host-tourist interaction for generating positive feelings through socialization, it is of utmost relevance to stimulate satisfying encounters between residents and visitors to maximize the positive impacts of tourism on residents' QOL.

\section{Conclusions and implications}

Despite the increasing interest in the impact of tourism on residents' QOL (Andereck \& Nyaupane, 2011; Andereck et al., 2007; Khizindar, 2012; Kim et al., 2013; Uysal et al., 2016; Yu et al., 2016) there is still a gap in the research concerning the factors that may influence this impact, particularly the role of host-tourist interaction. The results reveal that tourism has a crucial role in improving residents' QOL. The descriptive statistics provided show that tourism has a positive effect on all the four domains of QOL analyzed: calm \& safety (CS); public facilities \& services (PFS); and positive feelings (PF). However, the highest 
impact of tourism was observed in the QOL domains positive feelings ( $P F)$, economic \& social opportunities (ESO) and public facilities \& services (PFS), corroborating the study of Andereck and Nyaupane (2011). In contrast, the lowest impact occurred in the domain calm \& safety (CS), probably given that the tourism destinations under analysis are two coastal destinations with some pressure from tourists, mainly during the high season (between June and September). Regarding social contact, the results highlight that despite the host-tourist interactions being superficial and occurring with low frequency, as also pointed out by other researchers (De Kadt, 1979; Kastenholz et al., 2015, 2013; Reisinger, 2009), residents reveal a high level of satisfaction with these interactions.

In order to analyze the impact of host-tourist interaction on residents' QOL, a structural model was developed and tested in this article. This model explains about $50 \%$ of the variance of residents' perceptions of the impacts of tourism on their overall QOL and meets all the requirements. All the hypotheses were confirmed, revealing the important role of both intensity and satisfaction with host-tourist interaction on residents' perceptions of the impacts of tourism on their QOL. Findings reveal that, although the intensity of social encounters between residents and tourists is important for increasing tourism impacts on residents' QOL, satisfaction with these encounters has a slightly higher impact both in the majority of the QOL domains (with the exception of the calm \& safety domain) and, indirectly, on the overall QOL. Moreover, the results also reveal that the QOL domains positive feelings (PF) and public facilities \& services (PFS) are the two domains with the highest effect on residents' overall QOL. Although it is difficult to compare the results of this research with other findings due to the absence of studies that examine the structural relations among the constructs considered in this model, this study reinforces the relevance of non-material QOL domains such as positive feelings on residents' overall QOL, as evidenced by Woo and colleagues (2015). This points towards the crucial role of promoting satisfying social encounters between hosts and tourists to enhance the impact of tourism on residents' QOL.

Several theoretical and practical implications of this research may be mentioned. In a theoretical perspective, this article enables a better understanding of residents' QOL domains that are most influenced by tourism and of the domains that may have a higher influence on the overall QOL. It also extends knowledge on the determinants of the impacts of tourism on residents' QOL, namely the role of one determinant-social contact (intensity and satisfaction) - that has been highly neglected in the literature. This article also sheds light on the impacts of tourism on residents' QOL in coastal tourism destinations with a high seasonality, where ensuring satisfying encounters between hosts and tourists is of utmost importance for ensuring the sustainable development of these tourism destinations, considering that the satisfaction of all stakeholders is crucial to ensure sustainability (Choi \& Sirakaya, 2006). Moreover, some researchers (e.g., Andereck \& Nyaupane, 2011) also show that satisfying 
encounters may reduce conflicts between hosts and guests and may originate more positive host perceptions of tourism impacts, as well as more favorable attitudes toward tourism development (Kastenholz et al., 2013; Mathieson \& Wall, 1982; Nawijn \& Mitas, 2012; Pizam et al., 2000; Reisinger \& Turner, 2003; Su et al., 2016; Zhang et al., 2006).

The findings of this study also provide important practical implications for planners and managers of coastal tourism destinations. First, as the intensity of social encounters between hosts and tourists has a relevant role in increasing both the satisfaction with that interaction and residents' perceptions of the impacts of tourism on their QOL, it is crucial to involve residents in tourism planning and management. The promotion of tourism activities where residents are involved in the provision of services as guides or cultural brokers are only some examples of how the interaction between these two actors can be stimulated. It is also important for these encounters to be satisfying and rewarding for both intervening parties. Tourism managers could also encourage the development of events with an atmosphere that facilitates interaction.

Despite the important theoretical and practical contributions of this research, some limitations must be recognized. First, the temporal and geographical scope of the research is limited, since the research was carried out in an intermediary period between low and high seasons, in only two Portuguese coastal tourism destinations. It would be important to extend the data collection period in order to encompass both low and high seasons. Moreover, the research model proposed should be tested in other coastal destinations and also in other kinds of tourism destinations in order to understand if there are differences according to the level of tourism development of destinations or according to the type of destination (e.g., rural destinations, urban destinations). Second, despite an awareness that tourism may have both positive and negative impacts on residents' QOL, in this research only the positive impacts were analyzed. Undertaking studies that simultaneously consider negative impacts of tourism would extend knowledge in this field. Third, although PLS modeling in tourism research often employs single indicator constructs (Barnes, Mattsson, \& Sørensen, 2016; Zhang, $\mathrm{Li}, \mathrm{Su}, \& \mathrm{Hu}, 2017)$, it must be acknowledged that the use of a single item construct may impact the predictive validity of the model under study. Furthermore, although all the requirements for carrying out the PLS-SEM model seem to be met, an increase in sample size could contribute to an improvement of the model proposed. Finally, this study mainly relies on quantitative approaches to analyze the phenomenon under study. Despite the originality of the proposed model, it is of major importance to develop and test more structural models that examine the determinants of residents' perceptions of the impacts of tourism on their QOL incorporating other determinants (e.g., community attachment, sociodemographic profile and travel experience). Furthermore, the adoption of qualitative approaches to 
provide a deeper understanding on the two constructs under analysis-social contact and tourism impacts on residents' QOL-and on the relationships between these two constructs, is of great relevance to extend knowledge in this area, which has been widely neglected in previous research.

\section{References}

Andereck, K. L., \& Nyaupane, G. P. (2011). Exploring the nature of tourism and quality of life perceptions among the residents. Journal of Travel Research, 50(3), 248-260. doi:10.1177/ 0047287510362918

Andereck, K. L., Valentine, K. M., Knopf, R. C., \& Vogt, C. A. (2005). Residents' perceptions of community tourism impacts. Annals of Tourism Research, 32(4), 1056-1076. doi:10.1016/j.annals.2005.03.001

Andereck, K. L., Valentine, K. M., Vogt, C. A., \& Knopf, R. C. (2007). A cross-cultural analysis of tourism and quality of life perceptions. Journal of Sustainable Tourism, 15(5), 483-502. doi:10.2167/jost612.0

Aref, F. (2011). The effects of tourism on quality of life: A Case Study of Shiraz, Iran. Life Science Journal, 8(2), 26-30.

Ayeh, J. K., Au, N., \& Law, R. (2013). Predicting the intention to use consumer-generated media for travel planning. Tourism Management, 35, 132-143. doi:10.1016/j.tourman.2012.06.010

Bagozzi, R., \& Yi, Y. (1988). On the evaluation of structural equation models. Journal of the Academy of Marketing Science, 16(1), 74-94. doi:10.1007/BF02723327

Barnes, S. J., Mattsson, J., \& Sørensen, F. (2016). Remembered experiences and revisit intentions: A longitudinal study of safari park visitors. Tourism Management, 57, 286294. doi:10.1016/j.tourman.2016.06.014

Bimonte, S., \& Faralla, V. (2016). Does residents' perceived life satisfaction vary with tourist season? A two-step survey in a Mediterranean destination. Tourism Management, 55, 199208. doi:10.1016/j.tourman.2016.02.011

Bimonte, S., \& Punzo, L. F. (2016). Tourist development and host-guest interaction: An economic exchange theory. Annals of Tourism Research, 58, 128-139. doi:10.1016/j. annals.2016.03.004

Carneiro, M. J., \& Eusébio, C. (2011). Segmentation of tourism market using the impact of tourism on quality of life. Tourism \& Management Studies, 7, 91-100.

Carneiro, M. J., \& Eusébio, C. (2012). Tourist-host interaction: A cluster analysis of the youth market. International Journal of Tourism Anthropology, 2(3), 213-229. doi:10.1504/ IJTA.2012.050756

Carneiro, M. J., \& Eusébio, C. (2015). Host-tourist interaction and impact of tourism on residents' Quality of Life. Tourism \& Management Studies, 11(1), 25-34.

Chancellor, C., Yu, C.-P. S., \& Cole, S. T. (2011). Exploring Quality of Life Perceptions in Rural Midwestern (USA) Communities: An Application of the Core-Periphery Concept in a Tourism Development Context. International Journal of Tourism Research, 13, 496-507. doi:10.1002/ jtr.823

Chhabra, D., \& Gursoy, D. (2009). Life dynamism explorations on perceived quality of life and social exchange paradigms in casino settings. Leisure Sciences, 31, 136-157. doi:10.1080/01490400802685989

Chiappa, G. D., \& Abbate, T. (2016). Island cruise tourism development: A resident's perspective in the context of Italy. Current Issues in Tourism, 19(13), 1372-1385. doi:10.1080/13683500.2013.854751 
Chin, W. W. (1998). The partial least squares approach to structural equation modelling. In G. A. Marcoulides (Ed.), Modern methods for business research (pp. 295-336). Mahwah, NJ: Lawrence Erlbaum.

Chin, W. W., Marcolin, B. L., \& Newsted, P. R. (2003). A partial least squares latent variable modeling approach for measuring interaction effects: Results from a Monte Carlo Simulation Study and an Electronic-Mail Emotion/Adoption Study. Information Systems Research. Assessed 26 May 2016, http://pubsonline.informs.org/doi/abs/10.1287/isre.14.2.189.16018

Choi, H.-S., \& Sirakaya, E. (2006). Sustainability indicators for managing community tourism. Tourism Management, 27, 1274-1289. doi:10.1016/j.tourman.2005.05.018

De Kadt, E. (1979). Tourism: Passport to development? Perspectives on the social and cultural effects of tourism in developing countries. New York, NY: Oxford University Press.

Dolnicar, S., Lazarevski, K., \& Yanamandram, V. (2013). Quality of life and tourism: A conceptual framework and novel segmentation base. Journal of Business Research, 66, 724729. doi:10.1016/j.jbusres.2011.09.010

Eusébio, C., \& Carneiro, M. J. (2012b). Socio-cultural impacts of tourism in urban destinations. Revista Portuguesa De Estudos Regionais [Portuguese Review of Regional Studies], 30 (1), 65-76.

Eusébio, C., \& Carneiro, M. J. (2014). The impact of tourism on quality of life: A segmentation analysis of the youth market. Tourism Analysis, 19(6), 741-757. doi:10.3727/ $108354214 X 14146846679529$

Eusébio, C., Carneiro, M. J., \& Caldeira, A. (2016). A structural equation model of tourism activities, social interaction and the impact of tourism on youth tourists' QOL. International Journal of Tourism Policy, 6(2), 85-108. doi:10.1504/IJTP.2016.077966

Eusébio, C. A., \& Carneiro, M. J. A. (2012a). Determinants of tourist-host interactions: An analysis of the university student market. Journal of Quality Assurance in Hospitality \& Tourism, 13(2), 123-151. doi:10.1080/1528008X.2012.645201

Fornell, C., \& Larcker, D. F. (1981). Evaluating structural equation models with unobservable variables and measurement error. Journal of Marketing Research, 18(1), 39-50. doi:10.2307/ 3151312

Fredline, L., Deery, M., \& Jago, L. (2013). A longitudinal study of the impacts of an annual event on local residents. Tourism Planning and Development, 10(4), 416-432. doi:10.1080/ 21568316.2013.779314

Gefen, D., Straub, D. W., \& Boudreau, M.-C. (2000). Structural equation modelling and regression: Guidelines for research practice. Communications of the Association for Information Systems, 4(7), 1-78.

Guo, Y., Kim, S., \& Chen, Y. (2014). Shanghai Residents' Perceptions of tourism impacts and quality of life. Journal of China Tourism Research, 10(2), 142-164. doi:10.1080/ 19388160.2013.849639

Hair, J. F., Hult, G. T. M., Ringle, C., \& Sarstedt, M. (2014). A Primer on Partial Least Squares Structural Equation Modeling (PLS-SEM). Thousand Oaks, CA: SAGE Publications.

Hair, J. F., Ringle, C., \& Sarstedt, M. (2013). Editorial - Partial Least Squares Structural Equation Modeling: Rigorous Applications, Better Results and Higher Acceptance. Long Range Planning, 46(1-2), 1-12. doi:10.1016/j.lrp.2013.01.001

Henseler, J., Ringle, C., \& Sinkovics, R. (2009). The use of partial least squares path modeling in international marketing. Advances in International Marketing (AIM), 20, 277-320.

Henseler, J., Ringle, C. M., \& Sarstedt, M. (2014). A new criterion for assessing discriminant validity in variance-based structural equation modeling. Journal of the Academy of Marketing Science, 43(1), 115-135. doi:10.1007/s11747-014-0403-8

Huebner, A. (2015). Tourism and cultural encounters in 'the last frontiers'. International Journal of Heritage Studies, 21(9), 862-868. doi:10.1080/13527258.2012.661752 
INE. (2012). Anuário Estatístico da Região Centro - 2011 [Statistical Yearbook of the Central Region - 2011]. Lisboa, Portugal: INE.

Inoue, Y., Umezaki, M., \& Watanabe, C. (2012). Emergence of income inequality and its impact on subjective quality of life in an ethnic minority community in Hainan Island, China. Anthropological Science, 120(1), 51-60. doi:10.1537/ase.110523

Jaworski, A., Y-M., E. V., Thurlow, C., \& Lawson, S. (2003). Social roles and negotiation of status in host-tourist interaction: A view from British television holiday programmes. Journal of Sociolinguistics, 7(2), 135-163. doi:10.1111/1467-9481.00217

Jeon, M. M., Kang, M. M., \& Desmarais, E. (2016). Residents' Perceived Quality Of Life in a Cultural-Heritage Tourism Destination. Applied Research in Quality of Life, 11, 105-123. doi:10.1007/s11482-014-9357-8

Karabati, S., Dogan, E., Pinar, M., \& Celik, L. M. (2009). Socio-Economic Effects of AgriTourism on Local Communities in Turkey: The Case of Aglasun. International Journal of Hospitality \& Tourism Administration, 10(2), 129-142. doi:10.1080/15256480902851032

Kastenholz, E., Carneiro, M. J., \& Eusébio, C. (2015). Diverse socializing patterns in rural tourist experiences - a segmentation analysis. Current Issues in Tourism. doi:10.1080/ 13683500.2015.1087477

Kastenholz, E., Carneiro, M. J., Eusébio, C., \& Figueiredo, E. (2013). Host-guest relationships in rural tourism: Evidence from two Portuguese villages. Anatolia, 24(3), 367-380. doi:10.1080/13032917.2013.769016

Khizindar, T. M. (2012). Effects of Tourism on Residents' Quality of Life in Saudi Arabia: An empirical study. Journal of Hospitality Marketing and Management, 21, 617-637. doi:10.1080/19368623.2012.627226

Kim, K. (2002). The effects of tourism impacts upon quality of life of residents in the community. Dissertation submitted to the Faculty of the Virginia Polytechnic Institute and State University.

Kim, K., Uysal, M., \& Sirgy, J. (2013). How does tourism in a community impact the quality of life of community residents? Tourism Management, 36, 527-540. doi:10.1016/j. tourman.2012.09.005

Lee, C., Hallak, R., \& Sardeshmukh, S. R. (2016). Innovation, entrepreneurship, and restaurant performance: A higher-order structural model. Tourism Management, 53, 215-228. doi:10.1016/j.tourman.2015.09.017

Lee, Y., \& Weaver, D. (2014). The tourism area life cycle in Kim Yujeong literary village, Korea. Asia Pacific Journal of Tourism Research, 19(2), 181-198. doi:10.1080/ 10941665.2012.735681

Lipovčan, L. K., Brajša-Žganec, A., \& Poljanec-Borić, S. (2014). What is good for tourists should be good for residents too: The relationship between the quality of the touristic offer and subjective well-being of residents. Tourism Analysis, 19(6), 719-730. doi:10.3727/ $108354214 X 14146846679448$

Liu, Y.-D. (2015). Event and Quality of Life: A Case Study of Liverpool as the 2008 European capital of culture. Applied Research in Quality of Life. doi:10.1007/s11482-015-9391-1

Lundberg, E. (2015). The level of tourism development and resident attitudes: A comparative case study of coastal destinations. Scandinavian Journal of Hospitality and Tourism, 15(3), 266-294. doi:10.1080/15022250.2015.1005335

Mai, N. T. T., Rahtz, D. R., \& Shultz, C. J., II. (2013). Tourism as catalyst for quality of life in transitioning subsistence marketplaces: Perspectives from Ha Long, Vietnam. Journal of Macromarketing, 34(1), 28-44. doi:10.1177/0276146713507281

Mathieson, A., \& Wall, G. (1982). Tourism: Economic, physical and social impacts. New York, NY: John Wiley and Sons. 
Moscardo, G. (2009). Tourism and quality of life: Towards a more critical approach. Tourism and Hospitality Research, 9(2), 159-170. doi:10.1057/thr.2009.6

Moscardo, G., Konovalov, E., Murphy, L., \& McGehee, N. (2013). Mobilities, community well-being and sustainable tourism. Journal of Sustainable Tourism, 21(4), 532-556. doi:10.1080/09669582.2013.785556

Murphy, L. (2001). Exploring social interactions of backpackers. Annals of Tourism Research, 28(1), 50-67. doi:10.1016/S0160-7383(00)00003-7

Nawijn, J., \& Mitas, O. (2012). Resident attitudes to tourism and their effect on subjective well-being: The Case of Palma de Mallorca. Journal of Travel Research, 51(5), 531-541. doi:10.1177/0047287511426482

Pizam, A., Uriely, N., \& Reichel, A. (2000). The intensity of tourist-host social relationship and its effects on satisfaction and change of attitudes: The case of working tourists in Israel. Tourism Management, 21, 395-406. doi:10.1016/S0261-5177(99)00085-0

Polonsky, M., Hall, J., Vieceli, J., Atay, L., Akdemir, A., \& Marangoz, M. (2013). Using strategic philanthropy to improve heritage tourist sites on the Gallipoli Peninsula, Turkey: Community perceptions of changing quality of life and of the sponsoring organization. Journal of Sustainable Tourism, 21(3), 376-395. doi:10.1080/09669582.2012.699061

Rasoolimanesh, S. M., Jaafar, M., Kock, N., \& Ramayah, T. (2015). A revised framework of social exchange theory to investigate the factors influencing residents' perceptions. Tourism Management Perspectives, 16, 335-345. doi:10.1016/j.tmp.2015.10.001

Reisinger, Y. (2009). International tourism: Cultures and behaviour. Oxford, UK: Butterworth Heinemann.

Reisinger, Y., \& Turner, L. (1998). Cultural differences between Mandarin-Speaking tourists and Australian hosts and their impact on cross-cultural tourist-host interaction. Journal of Business Research, 42(2), 175-187. doi:10.1016/S0148-2963(97)00107-0

Reisinger, Y., \& Turner, L. W. (2003). Cross-Cultural Behavior in Tourism: Concepts and analysis. Oxford, UK: Elsevier Butterworth Heinemann.

Ringle, C. M., Wende, S., \& Becker, J.-M. (2014). Smartpls 3. Hamburg, Germany: SmartPLS GmbH. Retrieved May 26, 2016, from http://www.smartpls.com

Roehl, W. S. (1999). Quality of life issues in a casino destination. Journal of Business Research, 44(3), 223-229. doi:10.1016/S0148-2963(97)00203-8

Sharpley, R. (2014). Host perceptions of tourism: A review of the research. Tourism Management, 42, 37-49. doi:10.1016/j.tourman.2013.10.007

Sinkovics, R. R., \& Penz, E. (2009). Social distance between residents and international tourist-implications for international business. International Business Review, 18, 457469. doi:10.1016/j.ibusrev.2009.06.002

Su, M. M., Long, Y., Wall, G., \& Jin, M. (2016). Tourist-community interactions in ethnic tourism: Tuva villages, Kanas Scenic Area, China. Journal of Tourism and Cultural Change, 14(1), 1-26. doi:10.1080/14766825.2014.976228

Teye, V., Sönmez, S. F., \& Sirakaya, E. (2002). Residents' attitudes toward tourism development. Annals of Tourism Research, 29(3), 668-688. doi:10.1016/S0160-7383(01)00074-3

Tucker, H. (2003). Host-guest relationship and its implications in rural tourism. In D. L. Roberts, \& M. Mitchell (Eds.), New directions in rural tourism (pp. 80-89). Aldershot, UK: Ashgate.

Usher, L. E., \& Kerstetter, D. (2014). Residents' perceptions of quality of life in a surf tourism destination: A case study of Las Salinas, Nicaragua. Progress in Development Studies, 14(4), 321-333. doi:10.1177/1464993414521525

Uysal, M., Sirgy, M. J., Woo, E., \& Kim, H. (2016). Quality of life (QOL) and well-being research in tourism. Tourism Management, 53, 244-261. doi:10.1016/j. tourman.2015.07.013 
Wang, S., \& Chen, J. (2015). The influence of place identity on perceived tourism impacts. Annals of Tourism Research, 52, 16-28. doi:10.1016/j.annals.2015.02.016

Woo, E., Kim, H., \& Uysal, M. (2015). Life satisfaction and support for tourism development. Annals of Tourism Research, 50, 84-97. doi:10.1016/j.annals.2014.11.001

Wu, -W.-W., Lan, L. W., \& Lee, Y.-T. (2012). Critiquing the World Economic Forum's concept of destination competitiveness: A further analysis. Tourism Management Perspectives, 4, 198-206. doi:10.1016/j.tmp.2012.08.008

Yamada, N., Heo, J., King, C., \& Fu, -Y.-Y. (2011). Urban Residents' Life Satisfaction and cultural tourism development: The role of health perception, wealth, safety, community contentment, and cultural tourism development. Journal of Quality Assurance in Hospitality \& Tourism, 12(3), 220-235. doi:10.1080/1528008X.2011.541830

Yoo, J., \& Sohn, D. (2003). The structure and meaning of intercultural interactions of international tourists. Journal of Travel \& Tourism Marketing, 14(1), 55-68. doi:10.1300/ J073v14n01_04

Yu, C.-P., Cole, S. T., \& Chancellor, C. (2016). Assessing community quality of life in the context of tourism development. Applied Research in Quality of Life, 11, 147-162. doi:10.1007/s11482-014-9359-6

Zhang, F., Inbakaran, R. J., \& Jackson, M. (2006). Understanding community attitudes towards tourism and host-guest interaction in the Urban-Rural Border Region. Tourism Geographies, 8(2), 182-204. doi:10.1080/14616680600585455

Zhang, Y., Li, X., Su, Q., \& Hu, X. (2017). Exploring a theme park's tourism carrying capacity: A demand-side analysis. Tourism Management, 59, 564-578. doi:10.1016/j. tourman.2016.08.019

\section{Appendix 1. Results of the PCA on social contact}

\begin{tabular}{|c|c|c|c|c|}
\hline Variable & Communalities & $\begin{array}{l}\text { Factor } \\
\text { loading }\end{array}$ & Eigenvalue & Variance \\
\hline Close interaction $(\mathrm{Cl})$ & & & 3.313 & $25.49 \%$ \\
\hline Sharing meals with visitors & .767 & .846 & & \\
\hline Exchanging gifts with visitors & 740 & .844 & & \\
\hline Inviting visitors to one's home & .739 & .836 & & \\
\hline Practicing sports with visitors & .603 & .688 & & \\
\hline Participating in parties with visitors & 668 & 676 & & \\
\hline Interaction at work (IW) & & & 2.931 & $22.55 \%$ \\
\hline Connecting with visitors in the workplace & .702 & .823 & & \\
\hline $\begin{array}{l}\text { Interacting with visitors when providing them with } \\
\text { goods and services }\end{array}$ & .722 & .809 & & \\
\hline $\begin{array}{l}\text { Providing visitors with information about the } \\
\text { municipality }\end{array}$ & .524 & .701 & & \\
\hline Interaction in attractions \& facilities (IAF) & & & 2.146 & $16.51 \%$ \\
\hline $\begin{array}{l}\text { Contacting with visitors in other commercial } \\
\text { establishments }\end{array}$ & .63 & .773 & & \\
\hline Contacting with visitors on the beach & 637 & .761 & & \\
\hline Contacting with visitors in discos, clubs and bars & .586 & 718 & & \\
\hline $\begin{array}{l}\text { Contacting with visitors in food and beverage } \\
\text { establishments }\end{array}$ & .598 & .654 & & \\
\hline Contacting with visitors in events & .473 & 653 & & \\
\hline
\end{tabular}




\section{Appendix 2. Results of the PCA on tourism impacts on residents' QOL}

\begin{tabular}{|c|c|c|c|c|}
\hline Variable & Communalities & $\begin{array}{l}\text { Factor } \\
\text { loading }\end{array}$ & Eigenvalue & Variance \\
\hline Economic \& social opportunities (ESO) & & & 4.816 & $24.08 \%$ \\
\hline $\begin{array}{l}\text { Having the opportunity to participate in cultural } \\
\text { activities }\end{array}$ & .679 & .756 & & \\
\hline $\begin{array}{l}\text { Having the opportunity to carry on recreational } \\
\text { activities }\end{array}$ & .672 & .749 & & \\
\hline $\begin{array}{l}\text { Having opportunities to get more financial } \\
\text { resources }\end{array}$ & .681 & .747 & & \\
\hline Having more job opportunities & .633 & .739 & & \\
\hline $\begin{array}{l}\text { Having opportunities for contacting with people of } \\
\text { different cultures }\end{array}$ & .544 & .702 & & \\
\hline Having diversity of economic activities & .701 & .693 & & \\
\hline Having opportunities for socialising & .692 & .693 & & \\
\hline Calm \& safety (CS) & & & 3.980 & $19.90 \%$ \\
\hline Living in an unpolluted environment & .782 & .862 & & \\
\hline Living in a quiet environment & .767 & .809 & & \\
\hline Having a healthy life & .713 & .801 & & \\
\hline Feeling safe & .698 & .781 & & \\
\hline Living in uncongested environments & .619 & .766 & & \\
\hline Public facilities \& services (PFS) & & & 3.354 & $16.77 \%$ \\
\hline Having access to good transport & .802 & .829 & & \\
\hline Having access to health services & .736 & .718 & & \\
\hline Having facilities to promote mobility/acessibility & .726 & .695 & & \\
\hline Preserving cultural heritage & 699 & .602 & & \\
\hline $\begin{array}{l}\text { Having restaurants and other commercial } \\
\text { establishments }\end{array}$ & .583 & .576 & & \\
\hline Preserving the natural environment & .710 & .535 & & \\
\hline Positive feelings (PF) & & & 1.644 & $8.22 \%$ \\
\hline Feeling proud to live in this place & .689 & .814 & & \\
\hline Having positive feelings & .668 & .546 & & \\
\hline
\end{tabular}

$\mathrm{KMO}=.916$ Bartlett's test of sphericity $=3699.190(p=.000)$ 